\title{
Renewable Energy: Wind Turbines, Solar Cells, Small Hydroelectric Plants, Biomass, and Geothermal Sources of Energy
}

\author{
Nataša A. Kablar \\ Lola Institute, Kneza Viseslava 70a, Belgrade 11000, Serbia
}

\begin{abstract}
In this paper, we present five basic types of renewable energy sources, namely: wind turbines, solar cells, small hydroelectric plants, biomass, and geothermal sources of energy. Wind turbines transform energy of wind into electrical energy, solar cells transform energy of sun into electric energy, hydroelectric plants transform energy of water into electric energy, devices or machines can be constructed to transform energy of biomass into heat energy, and geothermal energy into some form of energy. In this paper we present basic information and reasons why there is need today to use these forms of energy-called green energies, we present how these devices or machines function, and we propose for future work design of typical devices or machines that will satisfy basic functional needs.
\end{abstract}

Key words: Wind energy, solar energy, water energy, biomass energy, geothermal energy, renewable energies, electrical power, generation of electricity.

\section{Wind Turbines: Transform Wind Energy into Electrical Energy}

Reason for using wind turbines-the wind energy is readily available, cheap, reduce gases emission, and saves water sources which are also used today. Wind is form of solar energy and is result of unequal warming of atmosphere with sun, the roughness of Earth's surface, and rotation about sun. It is vastly and often present [1].

Term wind energy or wind power describes the process through which mechanical power or electricity is produced by using wind turbines that converts kinetic energy of wind into mechanical power. This power can be further used in various applications, like griding grains, water pumping or producing electricity from generator that converts mechanical power into electricity.

Today wind turbines can be classified in two main groups: (1) wind turbines with horizontal axis, Fig. 1a, and (2) wind turbines with vertical axis, Fig. $1 \mathrm{~b}$.

Corresponding author: Natasa A. Kablar, Ph.D., research scientist, research field: control engineering.
Horizontal turbines typically possess two or three blends, which work upward wind, and with blends turned toward wind.

Wind turbines can be constructed on Earth surface, ocean costs or on big lakes. The power they produce is of order $100 \mathrm{KW}$ to several MW. Larger wind turbines are more efficient and are grouped together in so called - farms of wind turbines, which provides large amount of power to electric network.

Small wind turbines with power below $100 \mathrm{~kW}$ are used in homes, telecommunication devices, or for water pumping. They are sometimes used as supplemental with diesel generators, batteries, or photovoltaic systems. Combination of several energy sources is called hybrid systems and is typically used in localized places without electric network provided. Small or medium wind turbines are used for houses projects, farms, or social organizations [2].

Principle of work. Wind energy is produced via two or three blends rotating around rotor, which is being connected with main shaft, which drives generator in order to create electricity. 


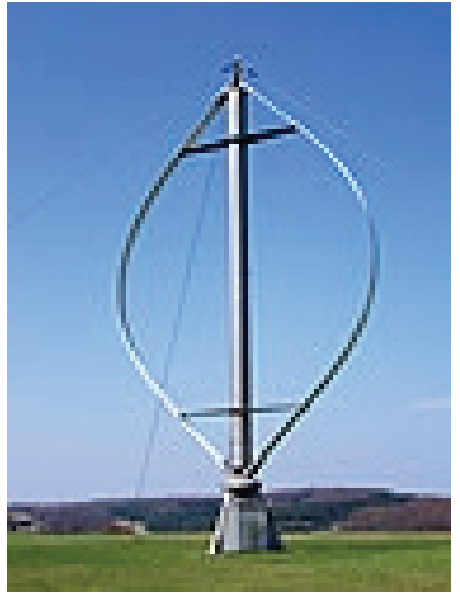

(a)

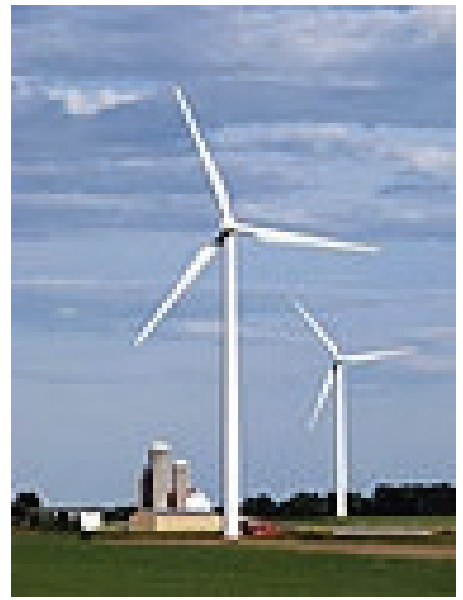

(b)

Fig. 1 (a) Vertical and (b) horizontal wind turbine.

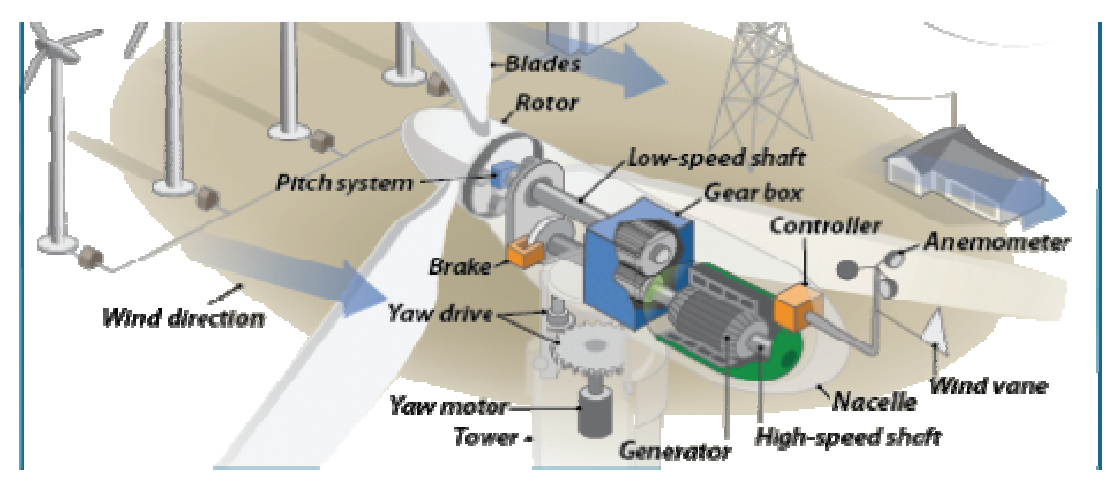

Fig. 2 Parts of wind turbine.

The main elements of wind turbine are: Anemometer, Blades, Brake, Controller, Gear box, Generator, High-speed shaft, Low-speed shaft, Nacelle, Pitch, Rotor, Tower, Wind direction, Wind vane, Yaw drive, and Yaw motor.

Development Task: Develop typical technical system of wind turbine in order to produce electricity from wind energy. Make operating assembly and working diagram and try to design your own elements.

Advances of wind energy usage: represents clean source of energy, domestic source of energy, sustainable, cheap, wind turbines can be constructed on existing farms, opens new jobs.

\section{Solar Cells: Transform Solar Energy into Electric Energy}

Solar cells transform solar energy into electricity. Solar revolution is idea that dates several decades back-sunny days can be used for sun energy collection which can be in form of electricity delivered to houses and working places. Today's usage of solar energy is obvious and is ever expanding [3].

The basic unit in solar energy transformation is solar or photovoltaic cell which converts sun energy into electricity, i.e. photons into movement of electrons. Group of solar cells connected is called solar module and is often packed into solar panels.

Solar cells are made of semiconductors as silicon is which ended up being good for the purpose of photovoltaic effect and conversion of sun energy into electricity. After sun energy falls into cell, certain amount is absorbed, and energy causes electrons to start moving freely.

Solar cells have one or more electric fields acting to direct electrons in certain directions. Movement of electrons represents electricity. By placing metal 

and Geothermal Sources of Energy

contacts on top and bottom of solar cell, we can drive out electricity for external use. This electricity together with voltage as results of electrical fields being present, defines electric power which can be produced from solar cell.

Today, it is popular to use green technologies that include solar cells for providing electricity in homes, working places, industry, and else.

The secret of making solar cell from silicone material lays in fact that silicon has special chemical properties, especially when it is in crystal form. Atom of silicon has 14 electrons in three shells with order 2 , 8 -internal shell, and 4, incomplete, external shell. That means that one atom of silicon with four other forms four pairs and therefore special crystalline structure, is very important for work of photovoltaic or solar cell.

The problem is weak conductibility of silicon, since no one of electrons can freely move. This is overcome with possessing impurities inside silicone, for example with presence of one atom of phosphorus with 5 electrons in other shell, which will by pairing 4 atom silicon electrons result with one free electron able to freely move. One extra proton in nucleus keeps the atom on place. When energy is added to pure silicon, it can cause few electrons to break the connections and leave atoms. Then the hole is formed. These electrons are called free carriers and are accidentally moving looking for other hole where they can fall carrying electricity. However, it is law number of this movement in clear silicon.

However, if the impurities are added to silicon different scenario appears. Firstly, it is needed much less energy in order to lose one electron of phosphorus not making electronic pair. As a result, the majority of these electrons are broken freely, and more free carriers do exist, than in pure Silicone. Process of impurity addition is called doping, and in case of adding phosphorus - it represents silicon of N-type, meaning negative type due to presence of electrons. It is a better conductor than pure silicone.
Two separate pieces of silicone are electrically neutral. When we connect N-type and P-type of Silicone, electric field starts to appear-electrons from $\mathrm{N}$-type are moving toward semiconductor of P-type, creating electrical barrier, junction that is coming to equilibria and through which electric field is formed. This electric field acts as diode.

When light in form of photons, comes to solar cell, energy brakes pair electron-hole. Each photon with enough energy will normally free exactly one electron, resulting with free hole. If this happens in electric field, filed will sent electron toward $\mathrm{N}$ side, and the hole toward $\mathrm{P}$ side. This enhances difference in electrical neutrality, and if we provide external electricity pathway, electrons will move along this pathway from $P$ side in order to join hole when electric field directs it in that direction, doing work along the way. Flow of electrons provides electric current, and electric field of solar cell causes voltage. With current and voltage, we get power, as product of these two physical values.

In order to construct solar cells, few more elements are needed. Since silicon is very bright material, that sends photons back before doing their part of job, it is necessary to place antireflective cover in order to reduce losses. Also, it is necessary to protect solar cells, which is done with glass power. More solar cells are arrayed into solar panel, on which ends are positive and negative terminals. Efficacy of solar cells is not high; it is about $12-18 \%$, with the most effective attaining $40 \%$ of efficacy.

Light that comes to solar cell has photons of wide range of energy, and some of them will not have enough energy to change pair electron-hole. Many photons possess a lot of energy. Only part of that energy, measured in $\mathrm{eV}$, is required to prevent loss of electrons. This defines energy of distance for material. If the photons have more energy than required, then much of the energy is lost. These two effects cause loss of $70 \%$ of radiation energy in photovoltaic cell. There are other losses as well. At the bottom of the solar cell it can be placed metal grid to provide conductivity. 


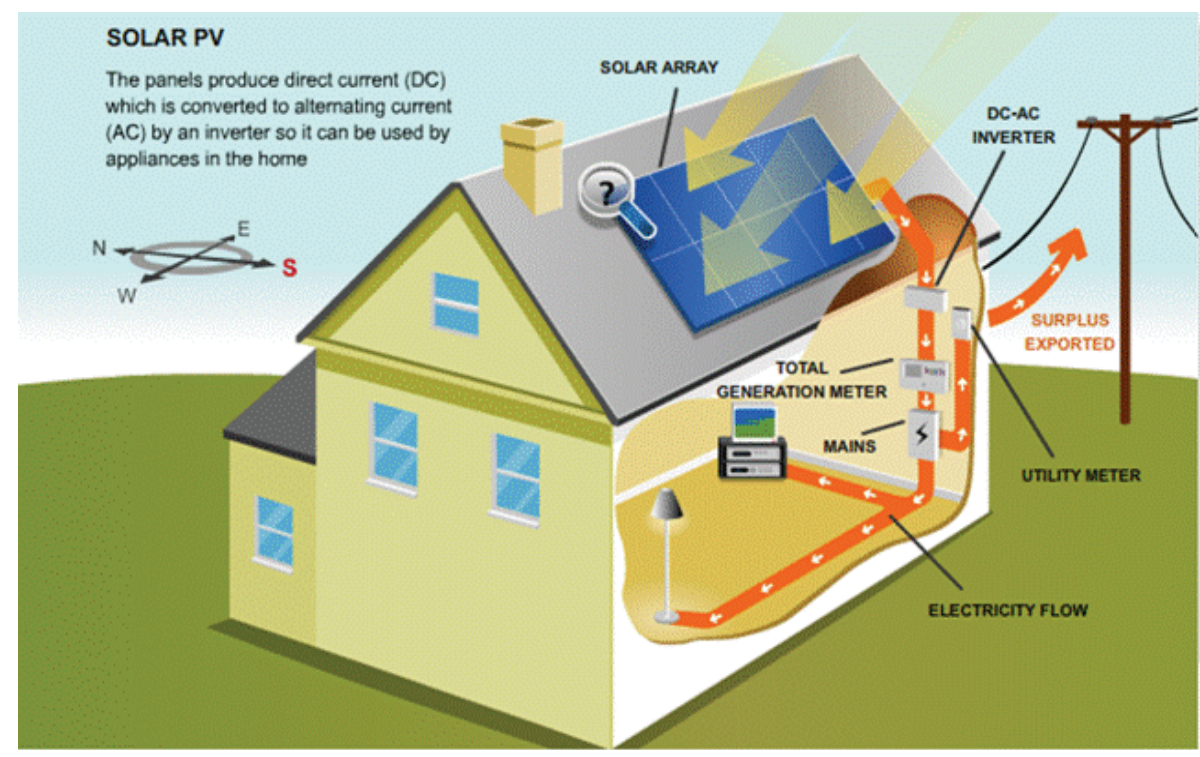

Fig. 3 Solar system installed at homes, main parts.

Let us present further typical solar system that can be placed in houses to provide electricity from solar energy. The basic building blocks are solar panels, generator, batteries (deep cycle, nickel cadmium, or lead acid), anti-islanding inverter, power controller, invertor, controller, electric wires, connectors, ground devices, DC and AC converters.

Development task: Design typical solar system that can be introduced in homes and used for producing electricity from solar energy. You might want to design certain elements in the system by yourself.

Low efficacy of solar cells results with numerous researches for development of better ways to utilize solar energy, one idea is to change silicon material to polysilicon material or use thin films of materials. Other strategy is to use concentrated photovoltaic technology (have optical devices for concentrating energy), or even use of organically produced solar cells at the level of nano scales.

\section{Small Hydroelectrical Plants: Transform Water Energy into Electric Energy}

In literature, development and implementation of small hydroelectric plants depends on what country is in question, what is the standard, what are the morphologic, topographical, hydrological and meteorology characteristics of the location, and what is degree of technological development. Parameter on which the small hydroelectric plant should be defined is power to be installed [4].

Sun energy as kind of heat comes to Earth surface and causes water, earth and botanical expiration, what causes water level elevation - the consequence is energy of water level (potential energy) and energy of water movement (kinetic energy). Energy of water level is initial kind of energy in nature and it can be used in technical transforming devices and systems for energy usage. The basic mechanistic principles are transforming of water level energy into kinetic energy of water, and further into rotational energy in turbines, and then into electrical energy in generators.

The simple system consisted of dam, canal with water, valve for water inflow, water, pipes, generator, turbine, controller, outflow of water, substation, electric grid.

Dam has multiple uses and redirect water from its natural flow towards capture of hydroelectric plant, rise of water level and viability of accumulation. Capture receives and directs water stopped from obstacle to hydroelectric plant. There exist two types of capture, on surface or under surface. Water comer is situated at the end of input tube. Dimensioning of input pipe has 


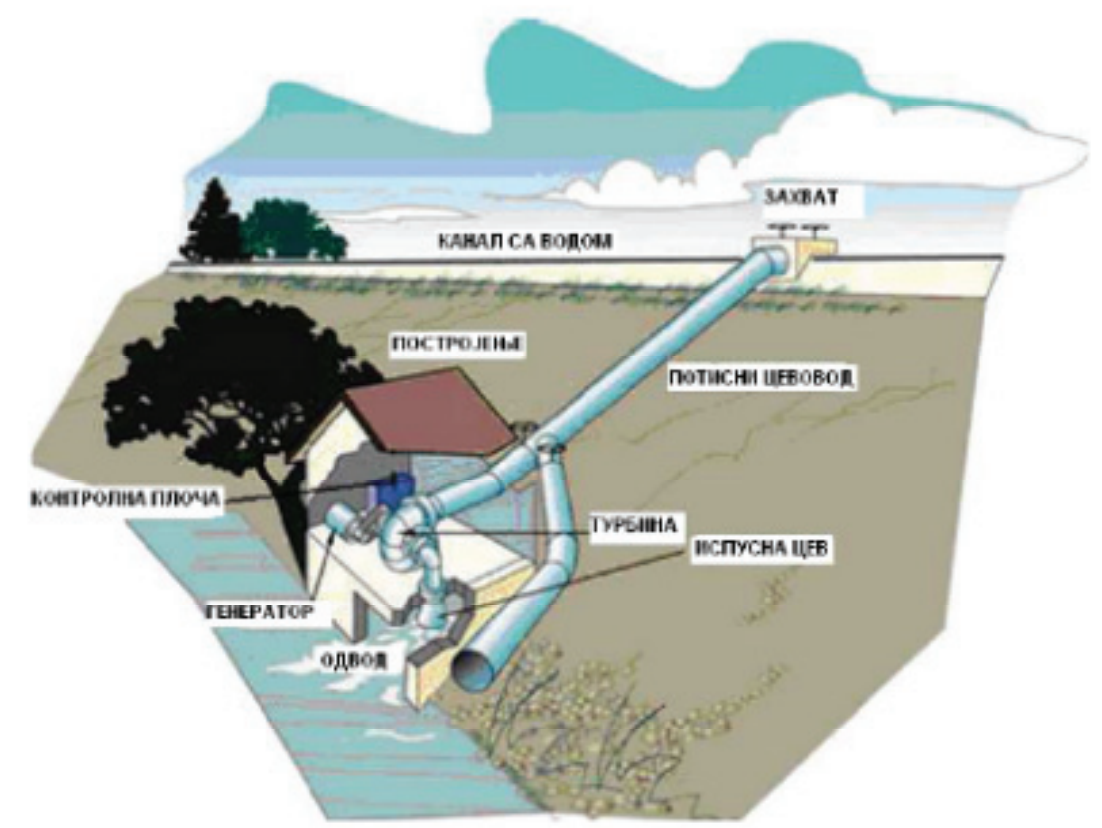

Fig. 4 Scheme of small hydroelectric plant.

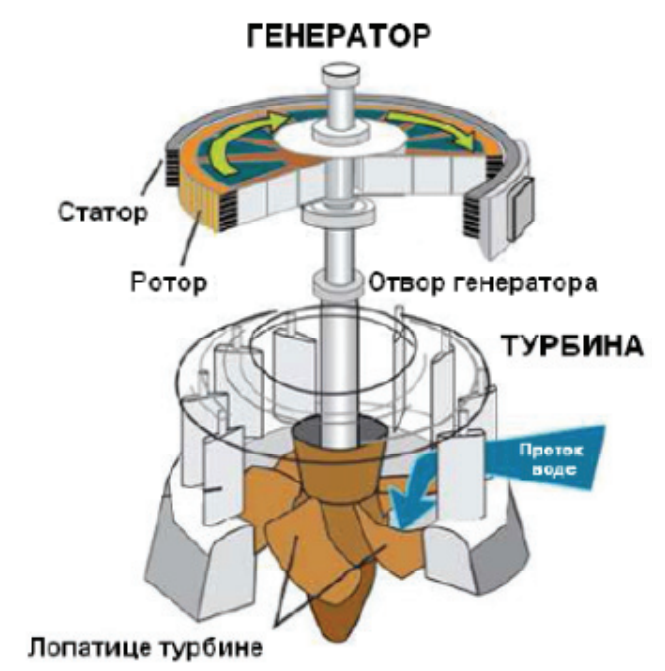

Fig. 5 Scheme of hydro turbine.

high impact on regular functioning of water comer. Income pipe connects capture with water comer. It can be developed as canal or tunnel. Tunnel can be developed as downward or gravitational. It serves for guiding water from water comer toward turbine. It is the most often designed from steel, and for smaller platforms from concrete. It is of trapezoid form.

In plant are situated generators together with turbines. Hydrogenators are designed mainly vertically, because of more economical use of hydraulic part of hydroelectric plant. Hydrogenators with horizontal design are used in plants with smaller power or when two Pelton or Francis turbines gain one generator. On the beginning of input pipe is placed device with safety role.

Water turbine is drive device in which potential energy of water is transformed into kinetic energy, and then to rotational energy. Turbine relates to generator in which rotational energy is transformed into electrical energy. Depending on the way how water energy is transformed, turbines can be reactional (downwards) or actional (free flow, impulse turbines).

The basic principles for choosing turbine type are level of water fall and quantity of flaw, usability, price, etc. There exist two types of turbines:

(1) Reactional turbines: Frances turbine (Francis, 1948), Kaplan turbines (Kaplan 1848), Kaplan turbine with stationary rotor blends.

(2) Turbines of free flaw (actional): Pelton turbine (Pelton, 1878), Turgor turbine (Pelton turbine variation, designed for higher specific velocities).

Small hydroelectric plants are ecologically acceptable, with electrical energy production, and it has no carbon emission. They reduce usage of fossils 
Table 1 Choice of turbine type.

\begin{tabular}{ll}
\hline Kind of turbine & Distance of falls (meters) \\
\hline Kaplan and propeller turbine & $2<\mathrm{H}_{\mathrm{n}}<40$ \\
Francis turbine & $25<\mathrm{H}_{\mathrm{n}}<350$ \\
Pelton turbine & $50<\mathrm{H}_{\mathrm{n}}<1,300$ \\
Banki-Michell turbine & $1<\mathrm{H}_{\mathrm{n}}<200$ \\
Turgor turbine & $50<\mathrm{H}_{\mathrm{n}}<250$ \\
\hline
\end{tabular}
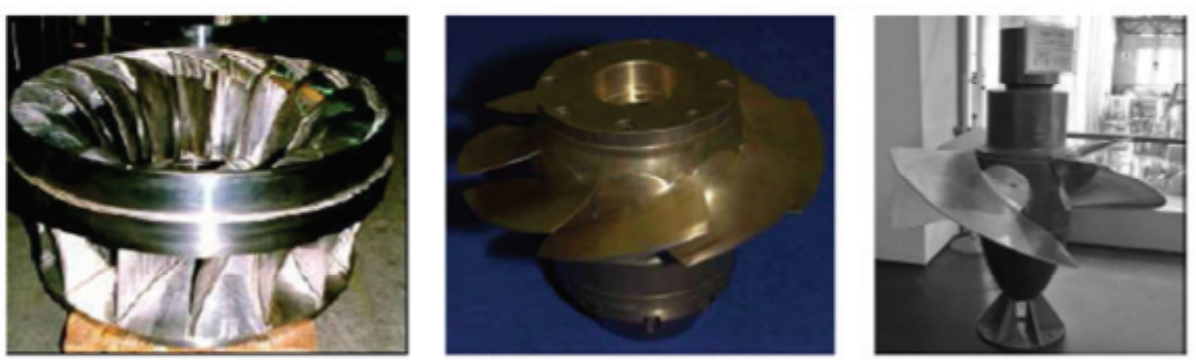

Fig. 6 Francis, Kaplan and propeller turbines.

Table 2 Installed small hydroelectric plants power in the world.

\begin{tabular}{ll}
\hline Country & Percentage \\
\hline Asia & 67.90 \\
Europe & 22.30 \\
United States & 8.90 \\
Africa & 0.50 \\
Australia & 0.40 \\
\hline
\end{tabular}

source of energy, help in flaw protection, do not require usage of large surfaces. One GWh of hydroelectric energy means avoidance of 480 tons of carbon dioxide, providing electrical energy through one year to 250 houses in developed countries or 450 houses in developing countries, and saving of 220 tons of fuel and 335 tones of coil. Although they do not influence water level changes as large hydroelectric plants, it has high influence on local flora and fauna which causes fish migration, water quality, etc., so it is needed to define measures of environmental protection.

Small hydroelectric plants are widely present in China, in Australia and New Zeeland are under development, Canada wants to change electrical plants on diesel fuel. Markets as South America, Russia, and Africa have great potential.

Advantages of usage small hydroelectric plants as renewable sources of energy are: no carbon emission into environment, control against flaws, suitable for providing electricity to isolated and inaccessible regions, and positive influence on region, in employment and similar. Disadvantages are fish migration, noise and vibration, visual changes in nature, changes in water flow in rivers, small accumulation, high investment costs and complexity.

Development task: Design typical small hydroelectric plant that will convert hydro energy into electricity. Think of the main elements and try to design main parts by yourself.

\section{Biomass Sources of Energy: Transform Energy of Biomass into Heat Energy}

Within industry for electricity production, biomass represents biological materials that can be used as fuel or for industrial purposes. It is measured as dry matter. Biofuels include bioethanol, biobutanol, biodiesel, and biogas. Biomass is produced from several plants including grass, hemp, corn, oats, wheat, willow, poplar, or sugar cane. What plant is chosen does affect 
process of transforming the raw materials. Production of biomass today for industrial purposes is growing industry, due to increasing interests for renewable energy sources [5].

Although biomass represents renewable source of energy, its usage causes global heating. That happens when natural balance of carbon is disturbed, by deforestation, or by urbanization in green cities.

Biomass is part of carbonic cycle. Carbon from atmosphere is converted in biological matter through process of photosynthesis. With decay or by combustion ended up being emitted into atmosphere. This happens in very small interval of time and matter for plant used as fuel can always be substituted with growth of new plant. Therefore, reasonable stable level of carbon in atmosphere is also result of using carbon as fuel.

Fossil fuels are not considered as biomass. Other usages of biomass are as material for building or biodegrade plastic or paper. Animal with the greatest biomass is Antarctic krill, Euphrasia superb, whose biomass is 500 million of tones, and almost two times more than biomass in humans. Whole Earth has 75 billion of tones of biomass. Humans are 250 million from that $(0.33 \%)$, domestic animals about 700 million (1.0\%), crops about 2 billion tons (2.7\%).

Biomass relates to net primary production. Factors that influence this production and therefore limit biomass accumulation, include: low level of rainfalls, low temperature, small amount of nutrients, short grow season. Factors that enhance net primary production and therefore increase levels of biomass are inverse of those listed above.

Development task: Think about how biomass can be used as biofuel. Think about device or machine which can be constructed and where from biomass the fuel can be produced. Think further how you can use biomass to produce electricity. Try to sketch working diagram of machine.

In Fig. 7, it shows the simplest machine for briquettes production.

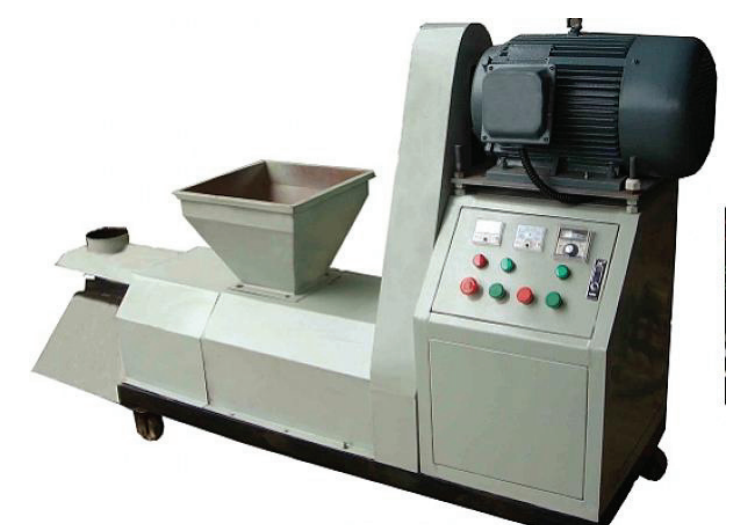

Fig. 7 The simple machine that produce briquettes from biomass for heat energy.

\section{Geothermal Sources of Energy: Transform Geothermal Energy into Some Form of Energy}

Geothermal energy comes from heat that is being developed beneath the Earth surface. Word geothermal has roots in Greek word geo meaning Earth, and thermo, meaning heat. Today geothermal energy is used for electricity production, for building heating, for greenhouses, and else [6].

At the centre of the Earth is iron in solid form surrounded with melted iron, on the temperature of 5,000 to 11,000 degrees of Fahrenheit. Earth core is on 4,000 miles below the surface. Heat is constantly produced by decay of radioactive particles that are natural in all rocks. Earth core is further surrounded by melted layer, which is partly in form of rocks, and partly in form of magma. It is 1,888 miles of width. The last layer of Earth is not consisted from continual layer of rocks, but from Earth plates that are pushing each other and drifting away with velocity of 1-2 inch per year. Magma can come very close to the Earth surface, and this heat can be used as usable form of geothermal energy.

Geothermal energy is renewable form of energy, since water can be renewed with rainfalls, and heat is continuously produced within Earth.

Ancient people, like Rome, Chinese, native Americans, have used hot mineral springs for bath, cooking, and heating. Usage of geothermal energy is 

and Geothermal Sources of Energy

relatively new industry, but as far as 1904 group of Italian engineers developed electrical generator in Larderello, Italy, which has been driven by natural stream that erupted from Earth. In USA first attempt was in 1922 at The Geysers, north California, but due to abrasion and particle corrosion, pipes and turbines fail. Today, this is the greatest source of geothermal energy where about 28 stations are placed. Electricity is produced today in 24 countries, both developed and not developed [7].

Characteristically sources of geothermal energy are volcanoes, hot springs, and fumaroles, where heat comes deep from Earth. In order to find geothermal source geologist, using some techniques including aerial photography, geological maps, they analyze local water sources chemically, and concentration of metals on location. They measure variations in gravitational and magnetic fields. But the only realistic way, is to drill wells in order to measure temperatures beneath the Earth.

The most attractive geothermal sources are on the boundaries of (tectonic) plates of Earth where volcanoes and earthquakes are concentrated. The majority of geothermal activities are within Ring of Fire, which surrounds Pacific Ocean, and is bounded with Japan, Philippines, Aleutian Islands, North America, Central America, and South America [8].

There exist four basic types of geothermal energy: hydrothermal, geo pressured, hot and dry rocks, and magma. First form is in wide use today, the other three are still under the development. Geothermal or hydrothermal resources appear where magma meets earth and heats water bounded in fractured or porous rocks, where water is circulated along ground faults. They can be used for various purposes, depending on their temperature and deepness.

When the temperature of hydrothermal resources is 50 Fahrenheit or more, they can be used directly in spas or for building heating, for growth corns, warming fish reservoirs, or for other purposes. They are suitable for heating and are used in 24 countries in the world. In
Islands hydrothermal resources are used for heating, more than 500,000 people in France use hydrothermal energy for heating public buildings, schools or homes. Also, in USA is widely used.

Heat from geothermal sources is used for drying ceramics, lumbers, vegetables, and other products.

When the temperature is about 220 degrees of Fahrenheit or more, hydrothermal resources can be used for electricity production. Majority of geothermal resources from which electricity is produced have temperatures in range 300-700 Fahrenheit.

Two main types of hydrothermal resources used for electricity production are: (1) reservoirs of dry steam, and (2) reservoirs of hot water.

The Geysers, in North California, are example of dry steam hydrothermal resources and are very effective in electricity production. Steam is gathered by wells drilling on 7,000-10,000 feet's of depth below Earth surface. Natural steam is then pumped directly from geothermal wells to turbine generator to produce electricity. Used steam or condensed water can be returned into geothermal reservoir in order to maintain water level and pressure.

Geothermal resources of hot water are the most often type. Reservoirs have plenty of water that dominates, and hot water cannot be transferred into steam because reservoir is saturated by water and is under the pressure. In order to generate electricity, hot water is pumped from geothermal wells in one or more separators where pressure is lowered and where water can be easily transformed into steam. Steam further drives turbine generator and electricity is produced. Steam cooling and condensation is next process, and is used either in cooling system of object or is returned back in geothermal reservoir.

Power plant with binary cycles is used when water in hot water reservoir is not enough to drive turbine generator. Hot water is surrounded with secondary fluid with lower boiling point and is vaporized under the pressure. This secondary fluid drives now the turbine generator. It is further cooled and recycled in 
order to be exposed to heat again.

Geothermal power plants can produce cheap electricity with price of 4-7 cents per $\mathrm{kWh}$. For comparisons, new thermoelectric plants produce electricity of price 4 cents per kWh. However, hydrothermal energy is renewable, and clean.

Starting construction is costly because of geothermal wells and power plants construction. But price of electricity due time is lower, and availability of dry steam or hot water is stable and predictive. Power plants are exactly on the top of the geothermal wells from which electricity is produced.

Emission of sulfur from automobiles and power plants on fossil fuels are cause of acid rains. Geothermal power plants emit only $1-3 \%$ of substances compared with fossil fuel or oil power plants. In case of well-designed binary cycle power station has no emissions.

Geothermal power plants are built in deserts, in the middle of corps, or in woods on mountains.

Development of geothermal power plants is usually allowed in state territories since they do not harm the environment. Before permit issuance it is necessary to perform study about the effect of power plant on environment. In protected national parks, geysers or fumaroles cannot be used as source of geothermal energy.

Geothermal power plants are like other power plants-heat obtained from energy source (in case of geothermal energy, earth core) is used for heating water or other working fluid. Hot working fluid further drives turbine generator producing electricity. Working fluid is then cooled and returned to source of heat.

Geothermal power plants on dry steam, given in Fig. 1a, directly use geothermal steam on 150 degrees of Celsius or more in order to start the turbine.

Geothermal power plants on flesh steam, given in Fig. 1b, pump out hot water from the Earth wells in tanks with lower pressure and use flash system for turbine start. They require temperatures of working fluid of about 180 degrees of Celsius, or more. It is the most often type of geothermal power station that is working today. Stations on flash steam use geothermal reservoirs on temperatures higher than 360 degrees of Fahrenheit. Hot water passes up through wells underground under its own pressure. Due to flow and height, pressure drops, and part of hot water starts to vaporize and turn into steam. Steam is further separated from water and is used for starting turbine generator. Rest of the water condensates and can be returned in reservoir, making potentially renewable resource.

Geothermal power plants with binary cycle can accept working fluid on temperature of 57 degrees of Celsius. Modestly hot geothermal water is surrounded with flow of secondary fluid with much lower boiling point than water. This causes secondary fluid to vaporize and start turbine generator. In design stage it used Rankin and Kalin cycle. Thermal efficiency is $10-13 \%$.

The International Geothermal Association, IGA announced data that at every moment (online) is available 10,715 MW of geothermal power in 24 countries of the world. Comparing to 2005 in 2015 is evidenced growth of $20 \%$.

In 2010, USA was the leading country in geothermal power production with 3,086 MW installed capacity in 77 power stations. The greatest group of geothermal fields is in The Geysers, North California. Today China is on the first place. Third country is Philippines with 1,904 MW, which consists $27 \%$ of electricity production in this country. First ten countries (of 24) enlisted in Today developed new enhanced geothermal systems that are working few kilometers in depth, and are operating in France and Germany, and are tested in four more countries.

Technologies used for producing electricity from geothermal energy are:

(1) Production of Geothermal electricity (from heat beneath Earth);

(2) Direct usage of geothermal energy (directly from hot water underground); 

and Geothermal Sources of Energy

Table 3 Installed geothermal power.

\begin{tabular}{lll}
\hline No. & Country & Installed geothermal power, data from 2015 \\
\hline 1 & China & 17,870 \\
2 & USA & 17,415 \\
3 & Turkey & 2,886 \\
4 & Germany & 2,848 \\
5 & France & 2,347 \\
6 & Japan & 2,186 \\
7 & Island & 2,040 \\
8 & Italy & 1,014 \\
9 & Austria & 903.4 \\
10 & New Zealand & 487 \\
\hline
\end{tabular}

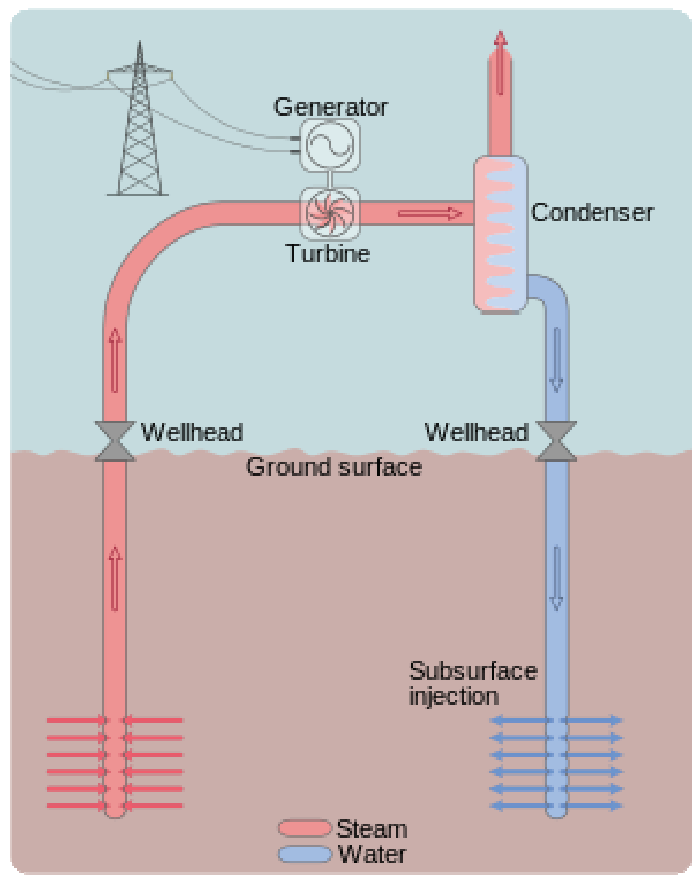

(a)

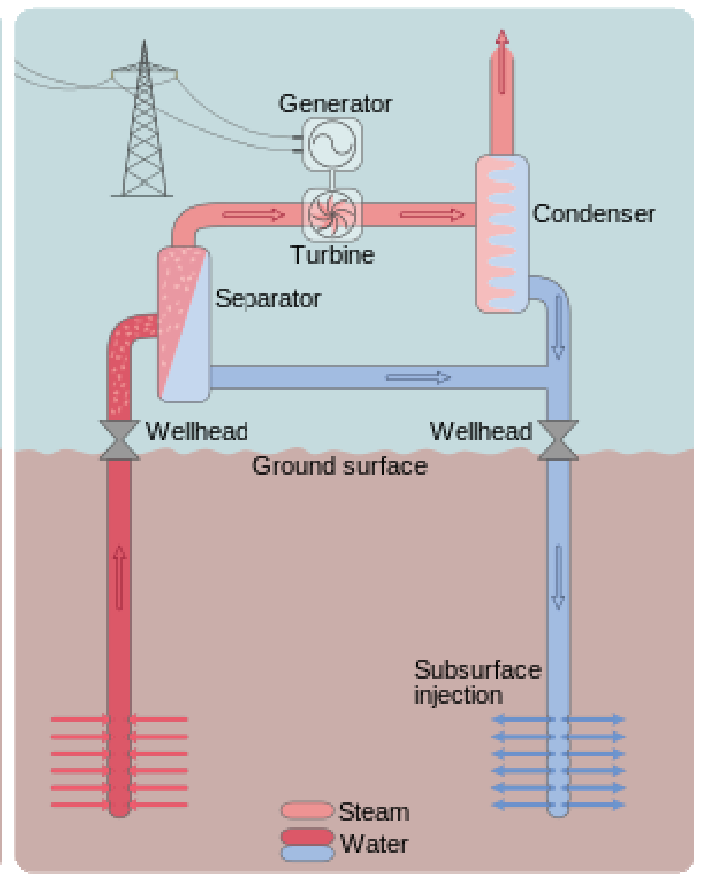

(b)

Fig. 8 (a) Dry steam and (b) hot water geothermal power stations.

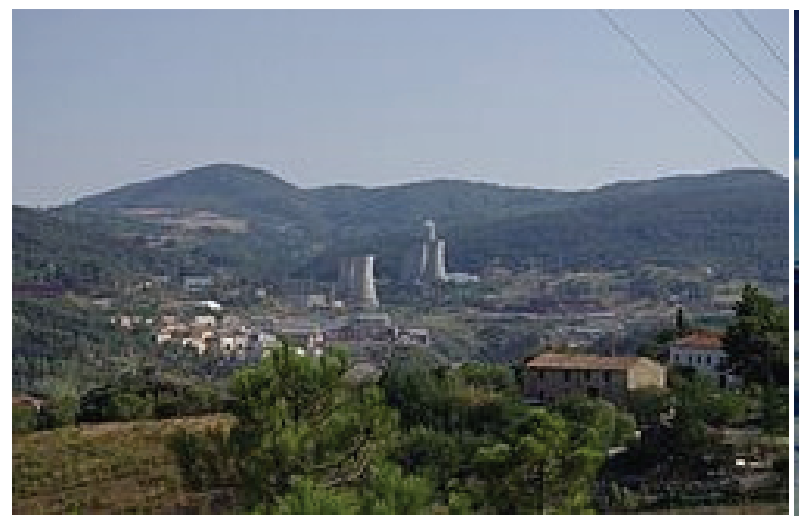

(a)

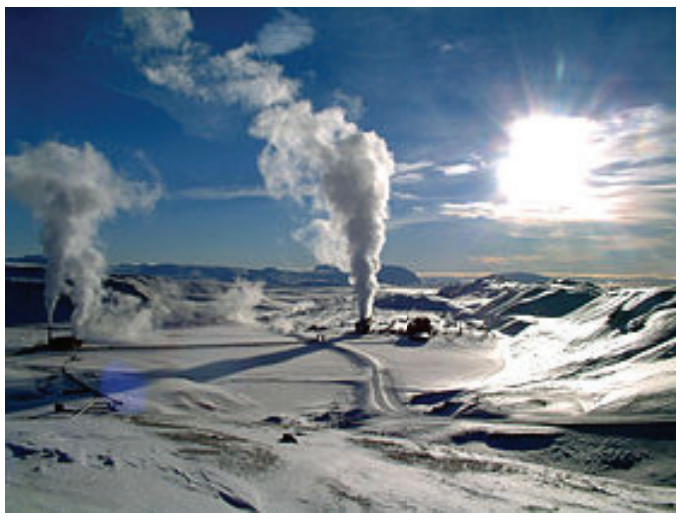

(b)

Fig. 9 Geothermal power plants in (a) Ladarello, Italy, and (b) Krafla, Islands. 
(3) Pumps of geothermal heat (by using water underground for building heating or cooling).

Geothermal heat energy obtained below the Earth surface can be used for generating clean, renewable energy. This vital, new and clean energy source provides renewable source all the time, and does not emit or emission of very small amount of harmful gases.

Currently, in USA are under construction five active Enhanced Geothermal Systems in Nevada, Idaho, Oregon, and California. Prediction says that EGS could provide $100 \mathrm{GW}$ of geothermal sources capacity which is enough for heating 100 million of homes.

It is formed Frontier Observatory for Research in Geothermal Energy (FORGE) from the US Department of Energy, which will present first laboratory for scientist and researchers for developing, testing and enhancing advancement of EGS technologies. It will also enable to collect and produce the data in real time and to identify paths for commercial EGS.

\section{Conclusion}

In this paper, we have presented five basic sources of renewable energy, namely wind energy, solar energy, hydro energy, biomass energy, and geothermal energy. All these kinds of energy via suitable transformations by using devices or machines can be converted into electrical energy. It is future task to design typical technical systems that will convert wind energy into electricity, solar energy into electricity, hydro energy into electricity, biomass into electricity, or geothermal energy into electricity.

\section{References}

[1] Renewable Energy. Wikipedia, https://en.wikipedia.org/wiki/Renewable_energy.

[2] Renewable Energy. USA Department of Energy, https://www.energy.gov/science-innovation/energy-sourc es/renewableenergy/.

[3] Renewable Energy World. http://www.renewableenergyworld.com/.

[4] Alternative Energy. http://www.altenergy.org/renewables

[5] Biomass Energy. http://www.biomassenergy.org.uk/.

[6] Geothermal Energy. https://www.geothermalenergy. org/what_is_geothermal_energy.html.

[7] Geothermal Energy. https://geothermal.org/what.html.

[8] Geothermal Energy Association. http://www.geoenergy.org/basics.aspx. 